УДК 176(038)

https://doi.org/10.18485/godisnjak.2019.14.6

Александра Б. Маринковић

Прегледни рад

Универзитет у Београду

Филолошки факултет, докторанд

Примљен: 15. 09. 2019.

Прихваћен: 11. 10. 2019.

\title{
ЕРОТОЛОШКИ РЕЧНИК ВЛАДИМИРА СЕРГЕЈЕВИЧА СОЛОВЈОВА ${ }^{1}$
}

Предмет ьубави нема у стварности онај значај који му даје машта заљубљеног човека.

В. С. Соловјов

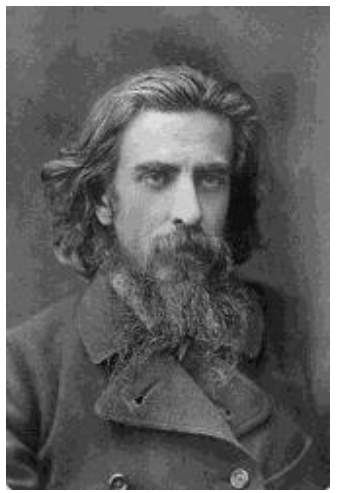

Владимир Сергејевич Соловјов (1853-1900) био је значајна личност у Русији у другој половини 19. века. Његова религиозна филозофија, као и поимања књижевности, утицали су на многе књижевнике и филозофе тог периода, пре свих на Ф. М. Достојевског, Л. Н. Толстоја и на руске симболисте. И сам је писао поезију, филозофско-теолошке расправе, етичке расправе о праву и сл. Његова најпознатија дела су Смисао љубави, Три сусрета, Идеја

${ }^{1}$ Три еротолошка речника написале су студенткиње докторских студија у оквиру предмета Књижевност и еротологија који на Филолошком факултету у Београду води проф. др Драгана Вукићевић. Будући да је еротологија специфична наука заснована на концептима а не методама, лексиколошки рад представља једну врсту иницијацијског приступа овој сложеној научној области, пионирски рад који отвара простор за нова мапирања радова најрелевантнијих еротолога. 
натчовека, Ex Oriente Lux и друге песме, Легенда о великом инквизитору, Духовне основе живота и друга.

Термине (појмове), који су у овом речнику објашњени, Соловјов је користио (дефинисао или објаснио) да би изложио концепт љубави који произилази из његове религиозне филозофије. Основна идеја те филозофије је Софија коју он поима као „Душу Света” - мистично космичко биће које обједињује Бога и овоземаљски свет. Њена суштина почива на вечитој женствености и Божјој промисли света. Сврха и значај полне љубави прихватљиви су само у том оквиру. Еротска љубав има смисла само ако се посредством ње дође до васпостављања лика Божјег у материјалном свету. Неки термини нису еротолошки, али су и они издвојени и објашњени јер се концепција еротолошког без њих не би могла сасвим појаснити.

Кључне речи: еротолошки речник, религиозна филозофија, концепт љубави, смисао љубави.

АПСОЛУТНИ (БЕЗУСЛОВНИ) ЗНАЧАЈ - смисао полне љубави (в. полна љубав) који се као индивидуално обележје приписује вољеном бићу супротног пола тако да оно постане јединствено и незаменљиво, „циљ по себи”, признавање апсолутног значаја је потврђивање људске вредности (то признавање је начело сваког веровања), непризнавање апсолутног значаја доводи до неверовања у себе, а онда не можемо веровати у било шта друго (у љубав), апсолутни значај се може реализовати само заједно са другима када се избрише замишљена граница између себе и других, „Признавати безусловни значај одређеној особи или веровати у њу (без чега истинска љубав није могућа) можемо само утврђујући је у Богу, дакле, верујући у самог Бога и у себе као онога који у Богу има средиште и основу свог бића." (Соловјов 1995: 42)

ВЕЧИТА ЖЕНСТВЕНОСТ - стање у коме се остварује свејединство (в. свејединство), стање у коме Бог испуњава божанском љубављу све оно што није Он Сам, а што је потенција (могућност) достизања бескрајног савршенства свега, па и љубави; „ништа”, оно пасивно те у том смислу и женствено, предуслов за реализацију полне љубави.

ВИШИ ПАТОС ЉУБАВИ - заљубљеност, стање у коме се вољеном бићу признаје апсолутни значај (в. апсолутни значај), привремено стање, првобитна снага љубави, ,машта која на одређено време овладава нашим бићем и ишчезава.” (Соловјов 1995: 22) 
ЕГОИЗАМ - самољубље, себичност, лажна самоувереност, негирање љубави и истине: 14), сила егоизма мора да се сукоби са силом сазнања у човеку да би се дошло до истине, а самим тим и до љубави: „Основна лаж и зло егоизма није у тој потпуној самосвести и самооцени субјекта, већ у томе што, оправдано приписујући себи апсолутан значај, он другима неоправдано укида тај значај; признајући себе за средиште живота, што он, у ствари и јесте, егоизам друге ставља на маргину свог постојања, признајући им само спољашњу и релативну вредност." (Соловјов 1995: 15-16); он (егоиста) је све, а други нису ништа, егоизам води у самонегацију и смрт.

ЗАКОН ИДЕНТИТЕТА ДИОНИСА И ХАДА - закон идентитета (јединства и непрестане борбе) живота врсте и индивидуалне смрти, закон супротности и борбе између врсте и јединке.

ИНДИВИДУАЛИЗАЦИЈА (И ЕГЗАЛТАЦИЈА) ЉУБАВНОГ ОСЕЋАЊА - сила љубави, посебна привлачна моћ, нешто изузетно, нешто незаменљиво, јединствено, „нешто што може да пружи потпуно блаженство" (Соловјов 1995: 5).

ИНДИВИДУАЛНА ЉУБАВ - сила љубави (посебна привлачна моћ) која је усмерена ка одређеној особи и стоји наспрам полне љубави (в. полна љубав).

ИНТЕГРАЦИЈА ЉУБАВНОГ БИЋА - процес остваривања истинске љубави, васпостављање лика Божијег у људском бићу.

ИСТИНСКО ЈЕДИНСТВО - јединство две стране људског бића (мушке и женске), јединство два начела: мушког (активног) и женског (пасивног): „Како се Бог односи према Својој творевини, како се Христос односи према Својој Цркви, тако је муж дужан да се односи према својој жени." (Соловјов 1995: 40); муж је дужан да ствара и обликује ум и карактер жене и да ствара своју „женску допуну” као што Бог ствара васељену и као што Христос гради Цркву.

ЉУБАВ - „процес васпостављања лика Божјег у материјалном човечанству” (Соловјов 1995: 27), „Истина која као жива сила овладава човековим бићем и која га истински чува од лажне самоуверености." (Соловјов 1995: 14). „Љубав је изнад разумског сазнања, али без њега она не би могла да делује као унутрашња спасоносна снага која уздиже, а не поништава индивидуалност. Само захваљујући разумском сазнању (или, што је исто, сазнању истине), човек може да разликује себе самога, тј. своју праву индивидуалност од свог егоизма (в. егоизам), и зато, жртвујући тај егоизам и предавајући се љубави, он налази у њој не само живу, већ и животворну силу и не губи заједно са егоизмом и своје индивидуално 
биће, већ га, напротив, овековечује.” (Соловјов 1995: 14-15). „Љубав је важна не као једно од наших осећања, већ као преношење целокупног нашег животног интересовања са себе на другога, као преношење самог средишта нашег личног живота.” (Соловјов 1995: 21). „Истинска љубав се пре свега заснива на вери" (Соловјов 1995: 42). Предмет верујуће љубави се разликује од предмета емпиријске (нагонске) љубави, иако постоји нераскидива веза међу њима. „То је једно те исто лице у два различита вида, или у две различите сфере бића - идеалној и реалној." (Соловјов 1995: 43)

ПОЛНА ЉУБАВ - реална (стварна, конкретна), сексуална, изузетна љубав (обострана или једнострана) међу особама различитог пола које могу да буду у односу мужа и жене, од других врста љубави се разликује већим интензитетом, већом посесивношћу и могућношћу потпуне узајамности, она није само средство за одржање врсте, код човека полна љубав добија највећи значај и највећу снагу, сједињујући максимално постојаност односа и јачину страсти, полна љубав је једина сила која изнутра поткопава егоизам (в. егоизам). Тако је „Привиђење предодредило”, а природа и историја то реализују, однос два бића који треба да буде „потпуна и стална размена”, „потпуно и стално потврђивање себе у другоме”, „потпуно узајамно деловање и општење” (Соловјов 1995: 18). „Само је при оваквом, такорећи хемијском једињењу два бића исте врсте и истог значаја, али потпуно различите форме, могуће (како у природном, тако и у духовном поретку) стварање новог човека, стварна реализација истинске човекове индивидуалности.” (Соловјов 1995: 18). Једино полна љубав може водити стварном и нераскидивом „саједињењу два живота у један” и „само је за њу и у речи Божијој речено: биће двоје у плоти једној, тј. постаће једно стварно биће.” (Соловјов 1995: 21)

ПОЛНИ АКТ - спољашње и пролазно сједињење два бића.

ПОЛНИ НАГОН - средство за одржање врсте, условно схваћено и појашњено у оквирима „природно-историјских чињеница” (велики број организама биљног и животињског света се размножава бесполним путем), способност размножавања опада са повећавањем полног нагона у природи (кичмењаци - рибе, водоземци, птице, сисари, човек).

ПРОТИВПРИРОДНИ СУРОГАТ ПОЛНЕ ЉУБАВИ - љУбав између два бића истог пола, хомосексуална љубав, љубав која одступа од прихватљивих норми сексуалног понашања.

PSYCHOPATIA SEXUALIS (термин преузет из тадашње психијатрије) - различити облици патолошких одступања од норми у полним односима (који захтевају лечење), ,аномалије из сфере сексуалног живота” 
(Соловјов 1995: 34), изопачени сексуални односи којима се одржава и овековечује царство греха и смрти, чисто физичка и чисто духовна љубав су такође облици девијантног понашања.

ПСЕУДООВАПЛОЋЕНИ ИДЕАЛ - просто поистовећивање љубавног идеала и вољене особе, као што су чинили средњевековни минезенгери и витезови који су имали јаку веру и слаб разум.

СИЗИГИЈА - (грч. спој, повезивање) однос узајамног деловања испуњеног љубављу, однос човека и идеје свејединства (в. свејединство) оваплоћене у социјалном и духовнотелесном организму.

СВЕТСКА ВОљА - воља за животом, несвесни или надсвесни светски дух, сила која покреће светски и историјски процес, сила која управља животом, Провиђење Божије.

СМИСАО ЉУБАВИ - „Смисао човекове љубави уопште јесте оправдавање и спасавање индивидуалности путем жртвовања егоизма" (в. егоизам) (Соловјов 1995: 16). Главни смисао љубави се састоји у признању безусловног значаја (в. апсолутни значај) другом бићу. „Али, у свом емпиријском бићу, које подлеже реалном чулном опажају, то биће нема безусловни значај: оно је несавршено по својој вредности и пролазно по свом трајању. Према томе, ми можемо да утврђујемо његов безусловни значај само вером, која је сведочанство испуњених надом, откривање невидљивих ствари.” (Соловјој 1995: 42)

СМРТ - дезинтеграција бића, распадање саставних чинилаца бића; „[...] подела између мушког и женског елемента људског бића је већ сама по себи стање дезинтегрисаности и почетак смрти." (Соловјов 1995: 33)

СПОЉАШЬА ВЕЗА - физиолошка (сексуална) веза, не подразумева никакав однос према љубави (могућа је без љубави и љубав је могућа без ње), али је неопходна љубави „не као њен обавезни услов и самостални циљ, већ само као њено коначно остварење" (Соловјов 1995, 29); ако се постави као циљ пре љубави, онда уништава љубав, спољашња веза по себи није ништа као нула, када се нула стави иза целог броја, увећава га десет пута, а када се стави испред њега, онда га за толико пута умањује или дели, одузима карактер целовитости.

ТВАРНО БИЋЕ - човек, овоземаљско биће, пропадљиво, биће чији су и живот и смрт условљени ограниченим временом и оивиченим простором; „биће у стању распадања, биће разбијено на делове и моменте” (Соловјов 1995: 52).

ФЕТИШИЗАМ (У ЉУБАВИ) - понашање које подразумева одступање од норми у полним односима (в. psychopatia sexsualis). „Код многих особа, готово увек мушког пола, то осећање се распаљује најчешће, а 
понекад и искључиво, помоћу једног или другог дела тела особе другог пола, (нпр. коса, рука, нога), а понекад и спољашњим предметима (одређени делови одеће итд.) [...] Ненормалност фетишизма се очигледно састоји у томе што се део поставља на место целине, припадност на место суштине.” (Соловјов 1995: 34)

HOMINEM DIVOMQE VOLUPTAS - оваплоћење божанске суштине у индивидуалном човековом животу посредством полне љубави.

\section{ЛИТЕРАТУРА}

Соловјов 1995: Владимир Сергејевич Соловјов, Смисао љубави, Београд: Логос - Ортодос, 1995.

Соловјов 1997: Владимир Сергејевич Соловјов, Духовне основе живота, Београд: Логос - Ортодос, 1997.

Соловјов 2006: Владимир Сергејевич Соловјов, Светлост са Исто$\kappa a$, Београд: Логос, 2006. 